\title{
Crossing Borders: The Case Of Mexican Tomatoes
}

Nita Paden, Northern Arizona University, USA

\begin{abstract}
The case involves distributors who import Mexican produce into the United States. To-Mex faces several problems. First, U.S. homeland security is at an all time high and is likely to continue growing tighter. The potential for delays at customs is significant. Second, Mexican produce has image issues in the U.S. market. Some American consumers have the perception that Mexican produce may not be safe to eat. Changing those perceptions is critical. The third issue relates to product strategies, including a possible move from predominantly field grown tomatoes to greenhouse operations, possible development of consumer brands for produce, and the potential effects of country of origin labeling on consumer produce preferences.
\end{abstract}

Keywords: Distribution; Country of Origin; Commodity Branding

\section{INTRODUCTION}

$\varnothing$ ack Barraza, president of To-Mex, a family-owned fresh produce distribution company based in Nogales, Arizona, squinted in the bright Sinoloan sun as he looked across the fields, and he was worried. It looked like a healthy crop of tomatoes and he knew that the production yield was up, but many of his competitors were devoting more resources to greenhouse tomatoes and he wondered if that was one of the changes he would soon be forced to make. "The whole industry depends on a good delivery and yet there are so many obstacles to getting there," he thought to himself.

Jack had flown down to Culiacan, Mexico, to talk face-to-face with his grower and long-time business partner, Enrique. Jack and Enrique, and their fathers and grandfathers before them, had been successfully growing tomatoes in Mexico for export to the U.S. for generations, but many changes were occurring in the produce industry and they knew that they would have to adapt in order to continue to survive.

\section{HISTORY AND CULTURE OF THE MEXICAN PRODUCE INDUSTRY}

Families in Nogales had been in the produce business for years. The fathers and grandfathers of the growers worked with the fathers and grandfathers of the distributors and in some cases, the fathers and grandfathers of others in the industry. One of the distributors explained it this way. "In our business everything is relationship based. Your father passes his relationships down to you and you will pass those relationships down to your son. This gives you a distinct advantage getting started. It is also the reason that major growers like Del Monte and Chiquita haven't been able to get a strong hold in northern Mexico." Some companies were vertically integrated, but most had simply developed extremely close relationships with other independent companies.

Competitors were also friends in this industry. Everyone in the industry knew everyone else. Amazingly, transactions among the channel members were still sealed with a handshake instead of a contract. Because it was such a unique industry in terms of the family-based model, if anyone failed to meet their obligation, they were essentially shut out of the industry. Word traveled quickly in this close-knit industry and no one would do business with a channel member who let them down.

Those close relationships did not necessarily mean that there was complete trust among the players, however. As Enrique said, "We get along fine with our competitors as long as we're not talking tomatoes." But 
often the needs of the industry took precedence over individual jealousies or competitions. Everyone in the industry had to work together to resolve problems facing them all. In the early days, all the Mexican growers came together to help the industry survive even though they were adversarial in business. This tradition and desire to keep the industry healthy continued.

But despite this tradition, there were business models other than the family based model beginning to come into the industry. A few companies in parts of the United States distributed produce through companies in Nogales but without salespeople in Nogales. Rather than walking through the fields and warehouses daily, the salespeople worked from a central office and relied on warehouse managers to tell them what was available. This seemed strange to the Nogales distributors. "People don't know what they are selling anymore," one distributor commented as he reached for a tomato and turned it over to check for blemishes. "How can they sell tomatoes without looking at them?"

\section{THE CHANNEL MEMBERS}

\section{The Growers}

The growers were responsible for maintaining the fields (and/or greenhouses), determining the best combination of crops, and managing the workers. The growers were also responsible for managing the packing facilities which were typically in close proximity to the fields. Growers often had thousands of employees. The field workers were from the southern states of Mexico. The packers were mostly local Mexicans and many had been working at their jobs for many years; for example, at one facility there were 30 people with over 30 years of employment. Many times a grower hired a head of household and his family. Because many of the workers were migrants from southern Mexico, the grower provided housing, healthcare and childcare for the families during the picking season. This was seen by the grower as both a social responsibility, as well as a way to improve the productivity of the workers since they did not have to worry about the welfare of their children while they were at work.

After the produce was picked, it was moved to the packing areas. Some of these were in open warehouses (called sheds), and others went to very tightly monitored and "sealed" warehouses. Regardless of the type of packing area, the produce was washed in a chlorine bath and then sorted by size and grade and packed for shipment to the distributors. Some sorting was done by hand, some by screens that dropped smaller produce to a second conveyor, and in some packing facilities, computerized digital computers took a picture of each tomato, recorded size and color and then sorted the produce automatically. Sanitation standards were strictly adhered to. Workers washed as they entered the facility, wore hair nets and masks, swept the floors continuously, etc. (Figure 1).

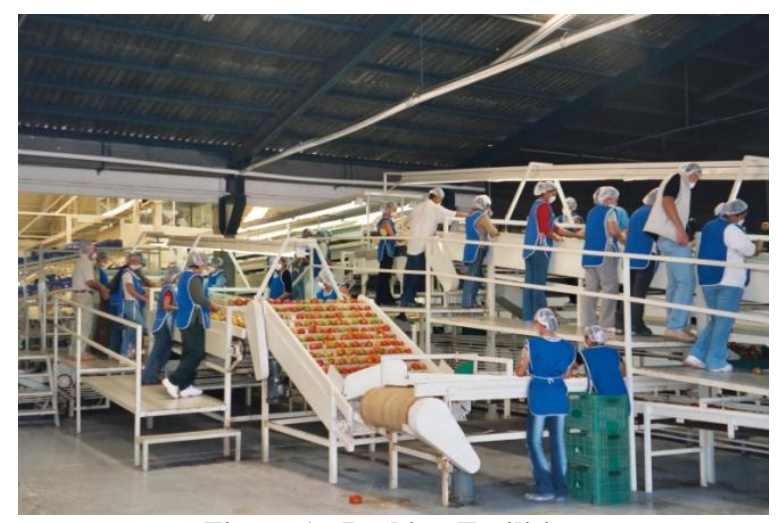

Figure 1: Packing Facilities

Some produce was packed in returnable plastic containers (RPC) and others in corrugated cardboard boxes and others in display ready containers (DRC). This was typically determined by the retailer. Some retailers (e.g., 
Wal-Mart) displayed produce in bulk in the carton and preferred the look of the DRCs. Weight of the cartons was an issue because OSHA limited the weight a person could lift. Produce that was determined not to be usable was routed to trucks and sold off as animal feed.

The growers did not sell directly to retailers. They sold to distributors. The grower notified the distributor by FAX nightly to tell them how many trucks were in route to the U.S./ Mexico border. Sometimes as many as 60 trucks a day headed from Culiacan to Nogales from a single grower.

\section{The Distributors}

Distributors predominantly sold their grower's brand, but also sold the brands of other growers. They also tended to specialize in a certain type of produce, but would try to get whatever their customer needed from other distributors. Distributors got an invoice from the growers so that they knew what produce was on its way to Nogales. The invoices were forwarded by the distributor to the customs broker so he could get the paperwork ready for the trucks that would be crossing the border. The distributors maintained a sales force that worked with customers and negotiated price. The salespeople specialized in different types of produce, but worked together to take care of customers. Distributors sold either to other distributors, to retailers, to companies who did further processing (e.g., slicing, canning), or to food service companies.

It was the sales force who set price. Price was determined by supply and demand like many other commodities. The weather played a critical role in pricing because of its effect on supply. If, for example, rain prevented harvesting of competitors' crops in Florida, Mexican produce prices increased. After the salespeople checked the weather in both their growing regions and the growing regions of competitors in the U.S. and talked to a few customers, they got a feel for supply and demand. They quoted a high price and then got a reaction to that price. Then, lots of negotiation occurred until the price was established. Consequently there was a lot of variation in margins earned. The price changed many times during the day; however, there was an unwritten policy that price did not change over the weekend.

The distributors built relationships with their customers and tried to help them find the product they needed when supply was short (as long as the customer didn't abandon them when the supply plentiful). They also talked to customers to find out what was going on with their competitors (e.g. what they have available to ship, prices, etc.)

The growers and distributors worked together to determine what product to pick. If for example, the distributor's customer wanted roma tomatoes, but the grower in Culiacan didn't have romas that were ready to pick, the distributor either got them from another one of their growers or managed the sale by informing the customer of the day that the romas would be available.

\section{Customs Broker}

Customs brokers handled the export/import paperwork for other channel members. They were licensed by the U.S. Department of the Treasury and were trained to have a thorough knowledge of tariffs and regulations affecting the importation of produce. Austin Roberts was Jack's customs broker. Austin's income was based on volume. He received about $\$ 55$ per truck. He did not have contracts with distributors which made his a fairly high risk job. "I'd prefer having contracts," said Austin, "but because of the tradition of family based relationships, I might offend my clients if I insisted on contracts. And anyway, I know who I'm dealing with. There have only been a couple of times that I didn't get paid. And they're no longer in the business." Customs brokers were originally used only by small distributors who couldn't handle all the paperwork, but now even large shippers like FedEx were using them because they were specialized and helped expedite the process.

\section{Commission Merchant or Broker}

This type of intermediary did not take title to (i.e. own) the produce. Instead, they found buyers for tomatoes and took around a 10\% commission on the produce they sold for the grower. Sometimes the distributor served this function. However, it was becoming less common unless a customer needed a specialty item and the distributor could not find it for them. 


\section{Retailers}

Retailers were the grocery stores and discount stores where the ultimate consumer bought fresh produce. Smaller retailers could buy from a distributor near their store location who had purchased from a distributor in Nogales.

\section{Food Service and Fast Food Companies}

Food service companies included distributors who sold food service to other institutions like hospitals, restaurants, and schools. An example of this type of company was Sysco.

\section{Further Processors}

Some produce was sold to companies who changed the form in some way. For example some companies sliced tomatoes to prepare them for sale to fast food restaurants. Canning companies would also be included as a further processor.

\section{THE NOGALES PORT OF ENTRY}

Nogales was the largest land port in the world for produce. The Nogales port handled over a billion dollars worth of produce each year. Fifty percent of the produce eaten in the U.S. and Canada in the winter came from Mexico. And $60 \%$ of produce that was grown in Mexico crossed the U.S. border at Nogales. Between November and March, approximately $90 \%$ of what crossed at Nogales was produce.

The Nogales port was extremely efficient for the number of trucks that crossed each day. Approximately 1200 trucks a day crossed at the Nogales facility even though it was built to handle 300 trucks a day. The customs compound was not open 24 hours a day. They started at 8:00 a.m. and stayed open until the line of trucks diminished. There was a commercial truck facility at the border to separate tourists/individuals from commercial crossings. This helped to accommodate produce growers and also anything that was produced by factories or maquiladoras in Mexico.

Both the Agriculture Department and the USDA operated at the port. The inspectors included homeland security, border patrol, department of agriculture, and the Arizona Department of Transportation (ADOT). The inspectors, depending on their area of expertise, were looking for drugs, illegal aliens, diseases or insects on produce and any potential threat to U.S. national security. Even the pallets on which the boxes were loaded were inspected for infestation.

As trucks came to the port of entry, various entry papers had to be presented. There had to be a detailed invoice stating where they came from, where they were going and country of origin ("made in" or "product of"). There had to also be a manifest describing what the driver was carrying (e.g. tomatoes) and the weight. A customs broker could be used to do the paperwork to make sure the driver had the proper documentation for entry along with the driver's personal identification. The driver was ultimately responsible for what was on the truck, even if a broker was used. The broker pre-files the paperwork electronically so it could be matched to what the driver was carrying and this expedited the border crossing process. Customs officials enforced the regulations.

As the truck came across the border there was a prescreening area where officials looked inside for anything that was blatantly illegal. After looking at the paperwork, the truck was either released or moved in for further scrutiny. If further inspection was required, the trucks were pulled into a dock area and the trucks were completely unloaded. Inspectors physically looked inside individual boxes. In addition the truck could be x-rayed. Mexican trucks had not been allowed to continue beyond the border, but the NAFTA agreement had included a schedule to open national borders to trucks from Canada and Mexico. Although this provision could have eliminated a time consuming transfer of produce between trucks, the provision had been met with significant controversy based on the concern that many Mexican-owned trucks did not meet the minimum safety standards. 


\section{Caades}

Caades was a cooperative of growers who had created a facility a few miles south of the border in order to complete their own inspections. This was not required, but added in an extra inspection (value-added) to help expedite the border crossing. They hired customs inspectors who checked quality and condition of produce. At the cooperative, they also checked load weights and corrected any overages prior to the truck crossing the border. Brokers maintained offices at customs and also at Caades. Growers paid dues to become members of the facility. About seventy percent of Mexican growers used Caades.

Jack knew it was getting harder and harder to move produce across the busy Nogales port of entry due to U.S. homeland security issues. Because of the perishable nature of produce, he knew this was no small issue. It took a truck 14 hours to get from Culiacan where Enrique's fields were, across the border and into Nogales where the distribution facilities were located. He was glad that a group of county and city based growers, brokers and distributors had recently formed the Nogales Port Authority to address problems faced by those using the port at Nogales.

\section{LEGAL ISSUES}

Various laws regulated what produce could be brought into the U.S. Sometimes these laws were to protect U.S. growers and could be issued by State. Also there were periodic restrictions based on identification of a particular pest in a country (e.g. fruit fly).Regulations about what could come into the U.S. could change daily. [See appendix A for relevant regulations.]

Jack was particularly concerned about two regulatory issues. It really made him mad that the Mexican tomato industry was currently obligated by The Tomato Suspension Agreement to not sell tomatoes under a minimum price (International Trade Administration, 2008). "It ties our hands when we are trying to be competitive on price. And we weren't dumping in the U.S. in the first place. U.S. growers just couldn't compete with us and so they said we were pricing too low. But a lot of factors impacted their supply, like the hurricanes in Florida, so their prices were naturally going to be higher than ours." Jack knew that the U.S. tried to protect its industries and he could appreciate that. But it also made it hard for U.S. importers of Mexican produce to stay in business and that didn't seem fair either.

\section{Country of Origin Labeling (COOL)}

Another proposed law that concerned him and others in the industry was country-of origin labeling (COOL). Mexican produce had always been labeled on the shipping crates. However, with the "COOL" laws, retailers were required to notify their customers of the source of produce like tomatoes (as well as some other agricultural products).Growers and distributors were concerned that it could significantly raise prices to both distributors and consumers.

Country of origin labeling was a part of the 2002 Farm Bill and required mandatory labeling of a variety of products including red meat, seafood and produce for the purpose of informing the ultimate consumer of the source of products. It originally established September 30, 2004 as the implementation date. Because of significant controversy, the implementation of this amendment to the Agricultural Marketing Act of 1946 was delayed until 2008 (usda.gov, 2009)

The debate surrounding COOL centered on whether COOL on individually purchased products was a consumer right to know issue or if it was actually a trade barrier to reduce competition from imports for U.S. producers. "We've always put 'Grown in Mexico' on our shipping containers," said Jack. "It's required by law for products entering the U.S. But if we have to put it (the label) on each individual piece of produce, it's going to drive costs up. And anyway, I'm not sure American consumers care where their tomatoes are grown if they taste good!" 


\section{PRODUCT ISSUES}

One of the difficulties faced by tomato growers was that the variety of tomatoes was continually growing and while consumer preferences appeared to be changing, consumer choices in produce were often moderated by what was available at their local retailer. Most of Enrique's tomatoes were going to the big retailers and they wanted quality (no blemishes) and size. He knew that he could grow bigger and less blemished tomatoes in greenhouses. However, based on his sales figures, it seemed that the demand for large tomatoes by ultimate consumers was declining. Consumers appeared to like variety including, shape and size (e.g. romas, on-the vine, grape), and even degree of ripeness and color (Table 1).

Table 1: Mexican Tomato Exports (to U.S.) by Type

\begin{tabular}{|c|c|c|c|c|c|}
\hline Year & Cherry & Grape & Greenhouse & Round $^{\mathbf{1}}$ & Roma $^{\prime \mid}$ \\
\hline 1995 & 40,889 & & & 391,797 & 160,337 \\
\hline 1996 & 41,975 & & & 429,710 & 213,992 \\
\hline 1997 & 39,281 & & & 409,229 & 212,098 \\
\hline 1998 & 50,307 & & 3,728 & 315,848 & 267,899 \\
\hline 1999 & 49,980 & & 27,468 & 277,995 & 257,467 \\
\hline 2000 & 37,834 & & 33,398 & 312,077 & 246,585 \\
\hline 2001 & 40,249 & & 42,140 & 309,262 & 315,817 \\
\hline 2002 & 39,291 & 16,915 & 58,357 & 323,456 & 345,892 \\
\hline 2003 & 32,379 & 25,086 & & & \\
\hline
\end{tabular}

${ }^{1}$ Includes both vine-ripe and green tomatoes

Source: U.S. Dept. of Commerce; Cook and Calvin Report, April 2005

\section{Green Tomatoes versus Red Tomatoes}

Green tomatoes (those with no pink) have to be exposed to ethylene gas in order to ripen and are stored in gas rooms (Figure 2).

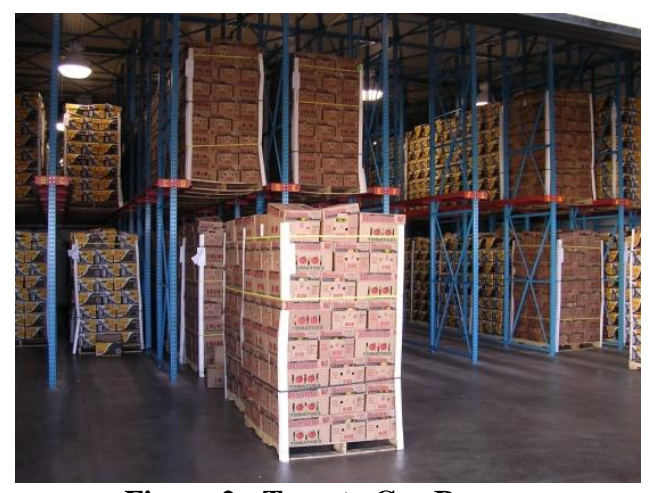

Figure 2: Tomato Gas Rooms

If the tomatoes had begun to ripen, they were considered vine-ripe because they would ripen without gas. Tomatoes picked green had little or no flavor. The longer tomatoes stayed on the stem the higher the sugar content and therefore they tasted better. Despite this fact, there was a strong demand for gassed tomatoes (i.e. greens) Gassed green tomatoes typically weren't in grocery stores. They went to fast food and food service companies because they were less juicy, and therefore sliced better and were less "drippy" on sandwiches. People in the industry used to predict that the market for greens would disappear, but because of the growth of food service and fast food, there continued to be growth in demand. A large portion of Jack and Enrique's business was in green tomatoes, and this had helped protect them from competition from greenhouse tomatoes. 


\section{Field Grown versus Greenhouse Grown Tomatoes}

There were many advantages to growing in green houses. First, it was more efficient to grow produce inside. Greenhouses produced more than open fields. 15 hectors ( 2.5 acres) could produce as much as 80 hectors of field grown produce. Also, produce could be picked regardless of the weather if the grower used greenhouses. It was also more efficient because the grower could control how water and fertilizer/nutrients were added. All irrigation and window movement (for temperature control) was computerized in greenhouses. Growers took weekly soil and foliage samples and adjusted fertilizer as needed. In the fields, watering and fertilizing was much more labor intensive and there was a lot of waste.

Secondly, growers could produce higher grades of produce (bigger and less blemished) indoors. Insects and disease couldn't get in and therefore the produce was not likely to be blemished. One of Enrique's competitors had already moved a large amount of production into greenhouses. "For cucumbers, you can get $88 \%$ supers in a green house versus $25 \%$ in open fields," he said. "There are customers for every grade, but supers get the best price and you can always go down on price if demand is low or there is a lot of competition." The major deterrent to switching from field to greenhouse was the investment. Greenhouses were very high cost endeavors. A very high technology greenhouse could cost over a million dollars to construct per hectare, not including the variable costs related to growing (Cook and Calvin, 2005), and the technology continually changed. The current design would withstand 80 miles per hour, but insurance was extremely high. The deductible was typically $25 \%$. In Mexico, the style of green house used was from Israel. They were not glass like the greenhouses in Holland because temperatures were higher in Mexico and there was less need to protect plants from the cold. Also Israeli growers were experts in irrigation and seed development because they had little water (Figure 3).

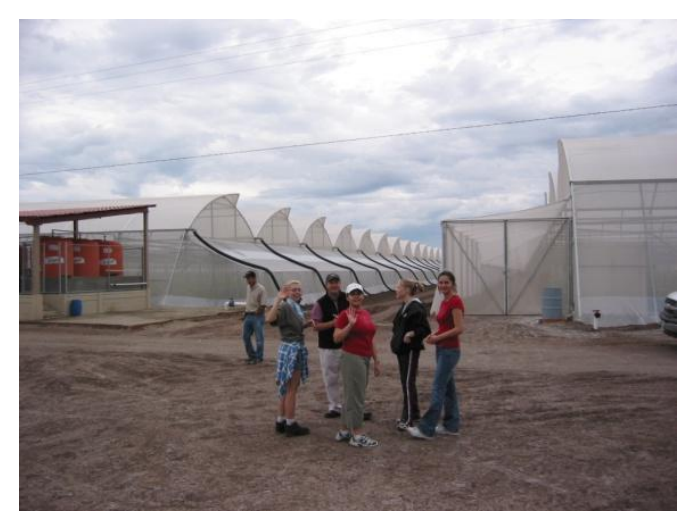

Figure 3: Mexican Greenhouses

Third, greenhouses allowed a grower to produce year round. This was a major advantage for regions where parts of the year prohibited field growing. However, Sinaloa's warm, humid climate made year round greenhouse production very costly. Jack and Enrique knew that the advantage that Mexican growers had from being able to grow tomatoes in the winter for shipment to the U.S. would be gone if major growers in the U.S. turned to greenhouse growing. However, Mexican greenhouse production of tomatoes was growing in importance and more and more hectares were being dedicated to greenhouse production (USDA Foreign Agriculture GAIN report, June 2010). In the U.S., greenhouse vegetable production was approximately twice as many hectares as in Mexico and tomatoes were the leading greenhouse crop (Diver, 2000).

\section{Branding}

The growers in Mexico and their distribution partners had developed brands for use inside the distribution channel. However, most of the brands were not directed to the ultimate consumer. Because produce was generally presented and sold in bulk to the ultimate consumer, there were fewer consumer brands in produce than in other categories of products. Of course, there were the major grower brands, such as Chiquita and Dole, but many growers 
had not attempted to promote their brands to ultimate consumers. However, Jack and Enrique and a few other Mexican growers had recently begun to experiment with consumer branding by putting product into "clamshell" packaging with labels to appeal to the ultimate consumer.

\section{FOOD SAFETY AND TRACEABILITY}

"Did you see that story in the newspaper about the woman who says she got salmonella from tomatoes on a convenience store sandwich?" asked Jack. "Yeah," replied Enrique. "Here we go again. Americans will be afraid to buy Mexican produce for awhile and the suspension agreement will keep us from lowering the price. I heard the FDA may even put a ban on tomatoes until they can trace the cause!"

Periodically there were news stories in which Mexican produce was linked to hepatitis, salmonella and other life threatening illnesses. In 2002, it was Mexican cantaloupes; more recently there were claims that people in Pennsylvania got sick from salmonella tainted tomatoes on convenience store sandwiches. There were quite a few examples of contaminated produce from Mexico, but there were also instances of U.S. farms being linked to the same diseases. But in either case, news stories had a significant effect on the perceptions that U.S. customers had about fruit and vegetables from Mexico. When the fruits or vegetables were traced to Mexico (either correctly or incorrectly), the FDA often established a ban on shipments of that fruit or vegetable for a period of time. Many growers and distributors felt it was unfair to punish all growers and packers of a category of produce when possibly one grower was to blame. FDA decisions of this type could be devastating to distributors and their growers who had already planted the banned item.

News stories in the U.S. describing incidents of possible bacteria or other contamination on Mexican produce created negative perceptions of quality, even though sanitation and safety control were monitored very closely in Mexican produce facilities. Misperceptions by U.S. consumers about Mexican produce created an advantage for U.S. producers because it caused customer reactions.

Enrique and other growers in Mexico were highly aware of the need to maintain sanitary conditions in the fields and packing sheds and were very careful. The water supply that went to the produce was monitored 24 hours a day. It was filtered first, then fertilizer with nutrients was added and then it was dispensed to the field via canals. In the U.S., much of the produce grown was field packed and therefore was distributed with minimal cleaning. In Mexico, the growers took all produce to the packing areas where it was cleaned before packing. They had to do this because of the volume being sold to U.S., and because of negative publicity about Mexican produce. They also kept records so they could trace a problem if needed. All boxes were bar-coded and the packers were paid by the box, so they could track who packed the produce as well as the productivity of the packer. Traceability had become a major issue to the entire produce industry (Produce Marketing Association, 2002) However, due to many organizations in the produce industry having proprietary traceability systems, those systems were often not integrated throughout the supply chain. Although PLU and UPC codes had been effective for most grocery products, produce industry experts felt that a separate standardized product identification would be beneficial throughout the produce supply chain (Industry Roadmap, 2007)

\section{HOW DO WE CHANGE?}

Jack scratched his head and then pulled his well-worn straw hat back in place as he walked back down the dirt road. He knew that he and Enrique were facing hard times if they didn't make some changes. But they couldn't just toss aside the successful methods of their fathers and grandfathers, could they? The question was how to leverage the historical success of the family business to meet the challenges of the future. Which pieces of the business should they continue and which required serious adaptation?

\section{ACKNOWLEDGEMENT}

The author wishes to express appreciation to Robert Bennen for sharing his insight into the produce distribution industry and for his comments on an earlier version of the case. 


\section{AUTHOR INFORMATION}

Nita Paden, Ph.D. (University of North Texas), is a Professor of Marketing at Northern Arizona University. Her primary research interests are in the areas of retailing, distribution channel relationships, higher education marketing and consumer behavior. Her research has been published in Journal of Consumer Marketing, Journal of Customer Service in Marketing and Management, Marketing Education Review, Journal of Marketing Channels and numerous national and regional conference proceedings. E-mail: nita.paden@ nau.edu

\section{REFERENCES}

1. Agricultural Marketing Service (2010), Country of Origin Labeling, www.ams.usda.gov

2. $\quad$ Araiza, A.E. (2004), "Crossroads: The Two Nogaleses," The Arizona Star, (February 26).

3. Barclay, Eliza (2003), "Cuba's Security in Fresh Produce," Foodfirst.org/media, (September 12)

4. Cook, Roberta and Calvin, Linda (2005), "Greenhouse Tomatoes Change the Dynamics of the North American Fresh Tomato Industry," Economic Research Service/USDA.

5. Countryoforiginlabel.org/consumer attitudes

6. “CPMA/PMA Announce Release of Fresh Produce Traceability, A Guide to Implementation," (April 11, 2005) www.pma.com

7. Diver, Steve (2000), “Organic Greenhouse Vegetable Production," National Center for Appropriate Technology.

8. "Fresh Produce Association Sees Voluntary Origin Labeling as Necessary Alternative," (July 22, 2004), http://www.fpaota.org/newsroom.

9. "Industry Roadmap: Building the Fresh Foods Supply Chain of the Future," (2007); a collective report of major U.S. fresh food associations.

10. International Trade Administration, 2008; www.trade.gov.

11. Krissoff, Barry and Kuchler, Fred (2004), "Mandatory Country-of-Origin Labeling - Will It Benefit Consumers?" Amber Waves, (April), U.S. Department of Agriculture Economic Research Center.

12. Means, Kathy (2003), "U.S. Country-of-Origin Labeling proposal: A Position Statement from the Produce Marketing Association," www.pma.com

13. Nelson, Andy (2005), "Industry Progresses in Protecting Produce Supply," The Packer (May 4).

14. “Tomatoes are Back as Mexico's Season hits Full Swing," (January 17, 2005), www.fpaota.org

15. "Traceability," (2009), The Produce Marketing Association white paper.

16. Vandervoet, Kathleen, (2002), "FDA Ban Stuns Produce Industry," Wick News Service (November 6), foodhaccp.com. 


\section{APPENDIX A}

The Plant Protection Act of 2000 (PPA): This law authorizes the secretary of agriculture to prohibit or restrict imports of plants if it is necessary to prevent the introduction of dissemination of a plant pest or disease (from The Produce Marketing Association 2005)

Trade Act of 2002: This law relates to many aspects of trade, but it specifically requires that the Bureau of Customs and Border Protection receive an advance electronic transmission of cargo information prior to the load moving across the border. Exporters must declare what is in the truck. There can be only one grower's produce per truck.

Antidumping and Countervailing Duty program (AD/CVD): This program is intended to help U.S. companies compete with foreign industry by prohibiting a foreign from price discrimination referred to as dumping. U.S. Customs and Border Protection, the Department of Commerce and the International Trade Commission play key roles in administering AD/CVD laws. Dumping occurs when a foreign producer sells a product in the U.S. at a price that is below that producer's sales price in its home market, or at a price that is lower than production (U.S. International Trade Commission 2005).

Tomato Suspension Agreement: Specifies minimum sales prices for improted tomatoes and establishes the conditions under which claims can be made by buyers (International Trade Administration 2008)

North American Free Trade Agreement (NAFTA): NAFTA established a free trade zone in North America and lifted the tariffs on the majority of goods coming into the U.S. from Mexico.

Country-of Origin Labeling (Farm Security and Rural Investment Act): Requires country of origin labeling (e.g. "Product of Mexico) on many products (including produce)

Bioterrorism Act: This act authorizes the Food and Drug Administration to detain an article of food at the border if there is an indication that it presents a threat of serious health consequences or death to humans or animals. (FDA 2004). 